\title{
Elements of a History of the Soul in North-West Semitic Texts \\ $\mathrm{npš/nbš} \mathrm{in} \mathrm{the} \mathrm{Hebrew} \mathrm{Bible} \mathrm{and} \mathrm{the} \mathrm{Katumuwa} \mathrm{Inscription}$
}

\author{
Joachim Schaper \\ University of Aberdeen \\ j.schaper@abdn.ac.uk
}

\begin{abstract}
Amongst Hebrew Bible scholars the question of the understanding of biblical key terms and concepts pertaining to the human condition has attracted a fair amount of interest. And amongst those key terms and concepts it is the concept of nefes that has proved to be particularly attractive and challenging. New light is thrown on the biblical concept by the recent discovery of the Katumuwa stele in Zincirli. The present article examines the evidence and draws conclusions with regard to the history of the concept of nefes in the Hebrew Bible and in North-West Semitic literature and religion generally.
\end{abstract}

\section{Keywords}

Aramaic inscriptions - biblical key terms and concepts - Genesis 35 - Katumuwa stele - nefeš - North-West Semitic literature and religion - soul - Zincirli

Amongst Hebrew Bible scholars of a variety of languages and traditions - and not just amongst those who take a special interest in social anthropology and its uses for the understanding of ancient Northwest-Semitic texts and artefactsthe question of the understanding of biblical key terms and concepts pertaining to the human condition has attracted a fair amount of interest. ${ }^{1}$ Amongst

1 Cf., amongst many others, B. Janowski, "Die lebendige ncefceš: Das Alte Testament und die Frage nach der 'Seele', in: idem, Der nahe und der ferne Gott: Beiträge zur Theologie des Alten 
those key terms and concepts it is the concept of nefes that has proved to be particularly attractive and challenging. Probably the main reason for that is the perennial interest taken in concepts of the "soul" in the Western philosophical and theological traditions. Recent decades have seen a shift of emphasis in the interpretation of nefeš, and many exegetes have claimed that the theological anthropology of the biblical authors excluded concepts of the soul as a material or immaterial entity distinct from the human body. That shift has had an effect on contemporary Bible translations and revisions in both the Jewish and Christian traditions. If, for example, we compare the ways in which the instances of nefeš in Ezek. 18:4 are rendered in the Revised Standard Version and in the New Revised Standard Version respectively, there is an interesting observation to make. The Hebrew text reads as follows:

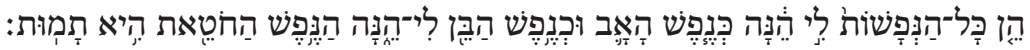

The Rsv has: "Behold, all souls are mine; the soul of the father as well as the soul of the son is mine: the soul that sins shall die." In the New Revised Standard Version, we read: "Know that all lives are mine; the life of the parent as well as the life of the child is mine: it is only the person who sins that shall die." The New JPs Tanakh gives the following rendering: "Consider, all lives are Mine; the life of the parent and the life of the child are both Mine. The person who sins, only he shall die."

The reluctance to translate nefeš as "soul" is palpable and most probably a result of the exegetical discussions of the term in the wake of the contributions of Johannes Pedersen, Hans Walter Wolff and others. ${ }^{2}$ The scholars who produced the New Revised Standard Version, as well as the translators of the New JPS Tanakh, obviously thought that the choice of "soul" in earlier translations had been inappropriate. Both groups of translators chose two English terms to render one and the same Hebrew term, which is a problematic decision at the best of times, and they tied themselves into knots: with regard to the last

Testaments 5 (Neukirchen-Vluyn, 2014, pp. 73-316); S. Niditch, The Responsive Self: Personal Religion in Biblical Literature of the Neo-Babylonian and Persian Periods (The Anchor Yale Bible Reference Library; New Haven and London, 2015), and A. Schellenberg, Der Mensch, das Bild Gottes?: Zum Gedanken einer Sonderstellung des Menschen im Alten Testament und in weiteren altorientalischen Quellen (Abhandlungen zur Theologie des Alten und Neuen Testaments 101; Zürich, 2011).

2 Cf. especially J. Pedersen, Israel, its Life and Culture, 4 vols. in 2 (London and Copenhagen, 1926-6940), and H. W. Wolff, Anthropologie des Alten Testaments (Munich, 1973); new edition: H. W. Wolff, Anthropologie des Alten Testaments: Mit zwei Anhängen neu herausgegeben von Bernd Janowski (Gütersloh, 2010). 
instance of nefeš in the verse, they realised that "life" would have been a nonsensical choice and went for "person" instead: the need for a rendering such as "person" or "soul" really is indeed inescapable here.

The exegetical trend that informs the two versions has been going hand in hand with the reasoning of Jewish and Christian scholars of religion and theologians who profess to have a deeper understanding of biblical concepts of personal eschatology than their predecessors in times past. By contrast, some philosophers and theologians have tried to revisit, re-evaluate and revive traditional views. However, in the study of biblical and other North-West Semitic literatures, too, there have been dissident voices-that is, voices that do not chime in with the chorus of those who deny that the Hebrew term nefes displays any traces of the concept of the human soul as an entity that is in some sense distinct from the body. The discussions between both camps have often tended to focus on some of the biblical psalms, and Psalms 16 and 49 have been at the centre of one of the debates.

I will need to go into a bit more detail regarding the exegetical discussion among biblical scholars, especially with a view to the psalms, and to the wider philosophical and theological context in which it is taking place. The exegetical and theological debate around the term nefeš and the conceptualization of the term with regard to views of the soul and the person has been particularly lively in German-language scholarship. There are those who argue for a (for want of a better term) monistic understanding of the human person and assume that the nefeš was considered to be inseparable from the body and would perish together with it. This is the view held, and argued in great detail, by_amongst others-Johannes Pedersen, Hans Walter Wolff, Christoph Barth and Bernd Janowski. ${ }^{3}$ Oswald Loretz turned against such interpretations of nefes in his compendious essay on Psalm 16 in which he advocates the understanding of nefeš, in Psalm 16, as "soul". Loretz provides a very detailed analysis of Psalm 16 and its use of nefeš and interacts with the opposing view, rightly devoting much space to the parallel debates in philosophy and theology. ${ }^{4}$

Ulrich Barth, a philosopher of religion on whose work Loretz partly relies, regrets that what he calls "archaizing and eliminative interpretations" of the

3 See the works mentioned in n. 2 as well as Janowski, "Die lebendige nœefces".

4 See O. Loretz, 'Die postmortale (himmlische) Theoxenie der $n p s ̌$ 'Seele, Totenseele' in ugaritisch-biblischer Sicht nach Psalm 16,10-o1: Die Ablösung der ugaritisch-kanaanäischen rāpiüma/Rōphe'îm/Rephaîm durch npš 'Seele (eines Toten), Totengeist' im Judentum”, Ugarit-Forschungen 38 (2006), pp. 445-597.

5 U. Barth, "Selbstbewußtsein und Seele", Zeitschrift für Theologie und Kirche 101 (2004), (pp. 198-817) p. 199: "in archaisierenden oder eliminativen Deutungen". 
relevant texts in the Hebrew Bible make it impossible adequately to understand the true complexity of the conceptualization of nefes in the Hebrew Bible. In Barth's view, this may be due to a present-day abhorrence of a certain type of supposedly Platonizing interpretations of the Hebrew Bible and the New Testament that are perceived to lead exegetes astray. ${ }^{6}$ Much could be said about the motives behind this resistance against allegedly Platonizing interpretations, which often remain unconscious, but this is not the place for it. Let us instead focus on the need to return to the biblical texts, to take their North-West Semitic setting seriously, and not to dismiss exegetical approaches out of hand simply because they are perceived to be either "archaizing and eliminative" or Platonizing and ahistorical.

What, then, do those who think that the concept of the "soul" can be found in the Hebrew Bible mean when they speak of the soul? Is it possible that their view is not simply an anachronistic, Platonizing aberration in the interpretation of the Hebrew Bible? First of all, we need to take on board that having a concept of the soul does not necessarily entail an endorsement of the $d u$ alistic Platonic conception of the soul, as expressed in Plato's Phaedo (79e$8 \mathrm{ob}$ ). There, Plato's Socrates describes the soul, while it is still joined to the body, as the ruling force and the body as the subordinate servant. ${ }^{7}$ Socrates' conversation-partner then concludes: "The soul resembles the divine and the body the mortal." And from that follows, according to Socrates, [8ob] "that the soul is in the very likeness of the divine, and immortal, and rational, and uniform, and indissoluble, and unchangeable; and that the body is in the very likeness of the human, and mortal, and irrational, and multiform, and dissoluble, and changeable".

It is the Platonic understanding of the soul that colours all talk about the soul to this day. Yet it is a fact that other concepts of the soul existed in the Mediterranean and the Near East in antiquity-idealist ones, like Plato's, and materialist ones, like those promoted by the Stoics. Of course we will not find a

6 Barth, "Selbstbewußtsein und Seele", p. 199. On the problem of the soul in modern Systematic Theology, cf. also K. Huxel, Ontologie des seelischen Lebens: Ein Beitrag zur theologischen Anthropologie im Anschluß an Hume, Kant, Schleiermacher und Dilthey (Religion in Philosophy and Theology 15; Tübingen, 2004) and eadem, "Unsterblichkeit der Seele versus Ganztodthese?-Ein Grundproblem christlicher Eschatologie in ökumenischer Perspektive", NZSTh 48 (2006), pp. 341-166.

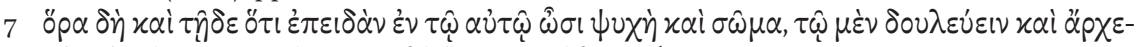

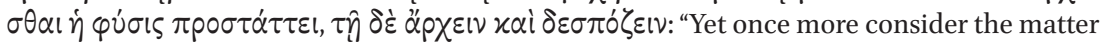
in another light: When the soul and the body are united, then nature orders the soul to rule and govern, and the body to obey and serve" (ET: B. Jowett, The Dialogues of Plato translated into English with Analyses and Introductions, vol. I, fourth edition (Oxford 1953), p. 434).

8 Jowett, The Dialogues of Plato, vol. I, p. 435 . 
Platonic understanding of the soul in the Hebrew Bible, but that does not necessarily mean that concepts of the soul generally are absent from the Hebrew Bible, as J. Pedersen and others have claimed. ${ }^{9}$

Important parts of the ongoing debate about anthropological terms and concepts in the Hebrew Bible took place before the Katamuwa stele was found and its inscription published. Since its publication, the discussion among scholars of North-West Semitic philology and biblical scholars has very much focused on the stele and its inscription in the immediate North-West Semitic linguistic and archaeological contexts. By contrast, I should like to focus on biblical texts that, in my view, conceptualize nefeš as "soul" or "person": after exploring the use of the cognate term in the Katumuwa inscription, I should like to apply the insights thus won to some biblical texts of key importance. As we shall see, the inscription, in the context of the stele overall and its cultic use, lends considerable support to one of the two opposing views of nefes in the Bible expressed in the recent exegetical, theological and philosophical debates.

The Katumuwa stele was discovered in Zincirli in Anatolia by the Neubauer expedition on 21 July 2008 and, amongst many other things, throws new light on the meaning and uses of *napš and its cognates in North-West Semitic and other Semitic literatures. From the point of view of Hebrew Bible scholarship, this is significant because the conceptualization of $n b s$ (the Aramaic term in the inscription, which is the cognate of Hebrew nefeš) adds a new dimension to the quest for the correct interpretation of nefes in the Hebrew Bible. Therefore I shall discuss the text and image found on the Katumuwa stele, but I shall not explore them for their own sake. Rather, I shall interpret them with the aim of using them as a key to a more subtle and differentiated understanding of the term nefes in the Hebrew Bible.

The lead questions for the purposes of the present paper will therefore be: 1) what does the Katumuwa stele say and show with regard to the supposed location and characteristics of the $n b s ̌$ as well as the ritual context and function of the stele itself? 2) Do biblical texts that employ the term nefeš, and do other ancient Near Eastern texts and artefacts, betray concepts that are cognate with the understanding of $n b s ̌$ informing the Katumuwa stele? 3) What light, if any, does the Katumuwa stele throw on the interpretation of the concept of nefeš in the Hebrew Bible?

9 Cf. Pedersen, Israel, vol. 1, pp. 99-981. 


\section{The Supposed Location and Characteristics of the $n b \check{s}$ According to the Katumuwa Stele's Inscription and Iconography and the Ritual Context and Function of the Stele}

On the basis of archaeological, palaeographic and philological considerations the stele can be confidently dated to the time of the reign of Panamuwa II. ${ }^{10}$ After it was initially thought that the inscription was written in Samalian, Pardee thinks — rightly, in my view - that it does not have a sufficient number of differential characteristics to make it anything but an example of a "previously unattested dialect of Aramaic"."11

This is the transcription offered by Pardee in his editio princeps: ${ }^{12}$

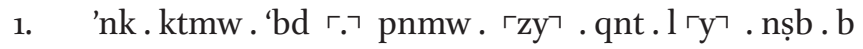

2. hyy . wšmt . wth . bsyr/d . 'lmy . whggt. s

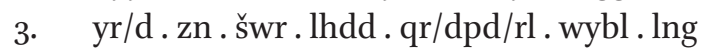

4. $\quad \mathrm{d} / \mathrm{r}$. șwd $/ \mathrm{rn}$.wybl . lšmš . wybl. lhdd . krmn

5. $\quad$ wybl. lkbbw . wybl. lnbšy . zy . bnșb .zn .

6. w't.mn. mn . bny.'w .

7. mn bny'š. wyhy. lh .

8. nsyr/d . znn . wlw yqh. mn

9. hyl. krm.znn. š'.

10. ywmn. lywmn. wyh

11. $\mathrm{rg}$. bnbšy

12. wyšwy

13. ly. šq

My translation, which uses Pardee's as its basis but differs from it with regard to a number of points, ${ }^{13}$ reads as follows:

1. I am Katumuwa, servant of Panamuwa, who commissioned for myself (this) stele while

2. [still] living. I placed it in my eternal [assembly-]chamber and [ritually] established $(h g g / h w g)$

10 D. Pardee, "The Katumuwa Inscription", in: V. R. Herrmann and J. D. Schloen (eds.), In Remembrance of Me: Feasting with the Dead in the Ancient Middle East (Oriental Institute Museum Publications 37; Chicago, 2014), (pp. 45-58) p. 46: The reference to Panamuwa refers "to the later of the two well-known kings of Sam'al who bore that name" and reigned from $743 / 74$ o to $733 / 732$ ВСЕ.

11 D. Pardee, "A New Aramaic Inscription from Zincirli", BASOR $35^{6}$ (2009), (pp. 51-11) pp. $5^{2-23}$.

12 Pardee, "A New Aramaic Inscription", p. 53.

13 Cf. Pardee, "A New Aramaic Inscription", pp. 53-34. 
3. this [assembly-]chamber [by sacrificing] a bull for Hadad QR/DPD/RL, a ram for $\mathrm{NGD} / \mathrm{R}$

4. SWD/RN, a ram for Šamš, a ram for Hadad of the Vineyards,

5. a ram for Kubaba, and a ram for my soul which is in this stele.

6. Henceforth, whoever of my sons or

7. of the sons of anybody [else] should come into possession of

8. this chamber, let him take from

9. the best of this vine[yard] [as] an offering

10. year after year. He shall also [ritually]

11. slaughter for my soul

12. and apportion

13. for me a leg-cut.

Let us first explore the way in which a channel of communication is established between the stele and the ancient readers of its inscription in the stele's ritual context.

The first remarkable fact is that the reader is being addressed by a disembodied first-person speaker: "I am Katumuwa". The Phoenician and Punic form of the 1st ps. sg. c. pronoun, ' $n h_{3}$, here occurs in an Aramaic text; cf. $K A I$ 214:1 and KAI 215:19 where the personal pronoun ' $n k$ occurs in Aramaic texts instead of the ' $n$ h one would expect. ${ }^{14}$ The disembodied "I" of the inscription is equated with Katumuwa's $n b \check{s}$, which is, of course, the Aramaic actualization of the original Semitic *napš, found in Hebrew as nefeš and in Arabic as nafs. The underlying idea is that of Katumuwa's $n b s ̌$ speaking from the stele, through the medium of the inscription. Thus, in a sense, the "I" is not disembodied at all. It speaks from the stele, which has been its abode ever since the event of Katumuwa's physical death. The fact that Katumuwa has physically died is implicitly conveyed when the inscription tells us that he commissioned the stele "while [still] living" (bhyy, l. 1-1). The reader is then informed that Katumuwa owns an "eternal [assembly-]chamber"-I am here reading syd, with Sanders ${ }^{15}$ — which he had had ritually established (whggt). The verb in question here is hgg, used in the pa"el or D-stem, as has been pointed out by Pardee. ${ }^{16}$ The verb, thus used in the causative and factitive sense, signifies the act of establishing the chamber (syd) as a place of ritual. This must be the correct reading: while there is a problem with the precise identification of dālet

14 Cf. the editors' comment in KAI, vol. II, p. 216: "אנך: pron. pers. abs. der 1. P. c. sg. Kanaanäisch!"

15 Pardee, "A New Aramaic Inscription", p. 6o, reads syr and tentatively reconstructs this as meaning "chamber".

16 Pardee, "A New Aramaic Inscription", p. 6o-o1. 
and $r \bar{s} s$ respectively in the Aramaic monumental script used at the stele's time of origin, syd makes sense as an actualization of the root $s-w-d$, as discussed by Sanders. ${ }^{17}$ The ritual of dedication clearly entails the sacrifice of a bull and four rams. The last of the rams in each celebration is to be offered "for my soul which is in this stele" (wybl. lnb̌̌y . zy . bnșb . zn; l. 5); zy here "introducing [a] relative subordinate clause". 18

The inscription consists of two parts which "are joined conceptually by the appearance of the word $n b s ̌$ [nabsh] 'soul' near the end of each section (lines 5 and 11), each time explicitly associated with the sacrifice of an animal, and by the explicit stipulation of how the 'eternal' chamber is to be maintained as such". ${ }^{19}$ The original dedicatory ritual thus established a recurring sacrificial ritual that was supposed to take place "year by year" (1. 10:ywmn lywmn). The ritual slaughter - the verb $\mathrm{hrg}$ is used —is to take place bnbšy (l. 11). Pardee translates "in (proximity to) my soul", but this should rather be rendered as "with regard to" or "for" my soul, Aramaic $b$ here being understood as meaning "with regard to". ${ }^{20}$ The inscription is thus predominantly occupied with ritual matters, ensuring the supply of the sacrifices needed for the eternal wellbeing of Katamuwa's nbš.

Let us now turn to the ritual context and the ritual actions and their significance. How did the ritual actually work, and how was it conceptualized? Is sacrifice for Katumuwa's $n b s$ a case of "feeding the dead", ${ }^{21}$ or is the "soul" present at the ritual without partaking in the eating? If my interpretation of the use of the preposition $b$ is correct, the soul was indeed thought to be fed the sacrifice. And there was nothing new to the concept of a $n b s ̌$ being fed; this practice was well known in the North-West Semitic world, as we shall see in a moment.

17 S. L. Sanders, "The Appetites of the Dead: West Semitic Linguistic and Ritual Aspects of the Katumuwa Stele", BASOR 369 (2013), (pp. 35-55) pp. 38-80. Sanders accepts the derivation of syd from $s-w-d$ on the basis of Epigraphic South Arabian evidence proposed by G. Mazzini, "On the Problematic Term syr/d in the New Old Aramaic Inscription from Zincirli", Ugarit-Forschungen 41 (2009), pp. 505-507.

18 J. Hoftijzer and K. Jongeling, Dictionary of the North-West Semitic Inscriptions, vol. 1 (Leiden/New York/Cologne, 1993), p. 310.

19 Pardee, "The Katumuwa Inscription", p. 46.

20 Cf. E. Vogt, Lexicon linguae Aramaicae Veteris Testamenti documentis antiquis illustratum, second edition (Rome, 1994), p. 24: de, quod attinet ad.

21 M. Suriano, "Breaking Bread with the Dead: Katumuwa's Stele, Hosea 9:4, and the Early History of the Soul", Journal of the American Oriental Society 134 (2014), (pp. 385-505) p. 387 . 
What does the image on the stele tell us? The interdepence of the inscription and the image must be taken seriously. ${ }^{22}$ As we heard, Katumuwa's $n b \check{s}$ is described as being present in (Aramaic $b$ ) the stele, which ties in with the stele's iconography. As pointed out by Bonatz, the Katumuwa stele is one of those stelae which "bear inscriptions [...] that confirm that the main figure [...] represents the deceased. As in the case of the Katumuwa Stele, the basic concept is that of a male or female person seated alone at the feasting table [...]. The visual focus is on the table, emphasized by food and drink laid on it near the cup in the hand of the seated figure."23 Katumuwa is enjoying a drinkprobably wine, as mentioned in l. 9-from the phiale which he holds in his right hand; food is on the table. If we try to understand what the image tries to convey to its beholder, the foodstuffs and drink are important. In his analysis, Bonatz writes: "The various types of food and drink offered to Katumuwa can in fact be seen as representing a source of continuous life and regeneration after death. He enjoys a quantity of bread, a portion of meat, and probably some sort of spices or aromatics kept in a luxury stone or ivory pyxis."24

It is quite fascinating that the Katumuwa inscription can be linked with other Aramaic inscriptions, ${ }^{25}$ inscriptions that have been known for a long time and were edited and commented on in Kanaanäische und aramäische Inschriften. The most important ones for our purposes are found in KAI 214 and 215. KAI 214 is an inscription dedicated by King Panamuwa I., whereas KAI 215 was dedicated by Panamuwa II. In 214, line 17 we read (the text is partly damaged), in the translation supplied in KAI: "[.]. und spricht: 'Möge die Seele des Panammuwa mit dir [es]sen, und möge die [S]eele des Panammuwa mit dir trin[ken']". This constitutes clear support for our earlier interpretation of line 11

22 Cf. I. J. Winter, "Royal Rhetoric and the Development of Historical Narrative in NeoAssyrian Reliefs", Studies in Visual Communication 7 (1981), pp. 2-28, a foundational study of the relation between text and image on ancient Near Eastern monuments in their spatial context.

23 D. Bonatz, "Katumuwa's Banquet Scene", in: V. R. Herrmann and J. D. Schloen (eds.), In Remembrance of Me: Feasting with the Dead in the Ancient Middle East (Oriental Institute Museum Publications 37; Chicago, 2014), (pp. 39-94) pp. 42-23. On Bonatz's viewbefore the Katumuwa stele was discovered - of the development of funerary monuments in Anatolia and Syria cf. idem, Das syro-hethitische Grabdenkmal: Untersuchungen zur Entstehung einer neuen Bildgattung in der Eisenzeit im nordsyrisch-südostanatolischen Raum (Mainz, 200o).

24 Bonatz, "Katumuwa's Banquet Scene", p. 39.

25 Cf. the discussion in R. C. Steiner, Disembodied Souls: The Nefesh in Israel and Kindred Spirits in the Ancient Near East, with an Appendix on the Katumuwa Inscription (SBL Ancient Near East Monographs 11; Atlanta, 2015), pp. 10-02 (chapter 1: "A Disembodied נבש at Samal and Its Ancient Near Eastern Kinfolk"). 
of the Katumuwa stele. In the last four lines of the Katumuwa inscription, the expressions "for my soul" and "for me" are clearly used in parallel: Katumuwa, as the donor of the inscription, thus takes for granted that the $n b s$ encapsulates the whole of his person. That ties in with the activities of the $n b s ̌$ described in $K A I 214$ and $K A I$ 215. This observation alone should advise against interpreting $n b s ̌$ simply as "life", "vitality" or the like. And the $n b s ̌$ is clearly Katumuwa's $n b s ̌$, it is tied to his name, as Matthew Suriano rightly points out. ${ }^{26}$

Summing up, we can conclude that the Katumuwa stele seems to combine the functions of a house for the $n b s ̌$ and an altar and that the $n b s ̌$ is conceptualised as an entity that equates the whole of the personality of Katumuwa, has continued to be alive and active beyond the point of his physical death, and now inhabits his stele.

\section{Are biblical texts that employ the term nefeš, and are other ancient Near Eastern texts and artefacts that do, similar to and possibly influenced by concepts that are cognate with the concept of $n b s ̌$ informing the Katumuwa stele?}

There is a multitude of biblical uses of nefeš, most of which are discussed in a wide-ranging essay by B. Janowski. ${ }^{27}$ For the purposes of the present investigation, I will concentrate on some uses of nefeš in a number of biblical texts that may — at first sight — not lend themselves to a comparison with the Katumuwa stele. I am not going to address Ezekiel 13:18, a fascinating text that is most likely informed by a particularly interesting conceptualisation of the soul. Yet it is not directly relevant to my argument, and it has been interpreted admirably by Richard C. Steiner in his remarkable study Disembodied Souls. ${ }^{28}$

First of all, I would like to draw the reader's attention to Genesis 35 . The text has a complex literary history, of which more in a moment. In Genesis 35 we find, amongst other things, the narrative of the death of Rachel. It is described in the following terms, in. v. 18:

\footnotetext{
26 Suriano, "Breaking Bread", p. 39o.

27 Janowski, "Die lebendige nøefces", passim.

28 The central part of Steiner, Disembodied Souls, focuses on Ezekiel 13:17-71 (pp. 23-37); attention is paid to Genesis 35 (pp. 3, 63, 69, 71-12, 94, 96, 101-101, 125; under the general heading of "Disembodied נפשות Elsewhere in the Hebrew Bible", pp. 68-80), but not to the reconstruction of the sources of Genesis 35 and the implications a source analysis has for the interpretation of the crucial passages. Steiner does not really discuss Psalm 16, but cf. the mention on p. 3.
} 
18

In the translation of the RSv: "And as her soul was departing (for she died), she called his name Ben-o'ni; but his father called his name Benjamin.”

After Rachel's burial Jacob acts as follows (v. 20):

$$
20
$$

The Rsv translates: "and Jacob set up a pillar upon her grave; it is the pillar of Rachel's tomb, which is there to this day".

While the text of Genesis 35 in its present form does not say explicitly that the mașşēba which Jacob puts up for Rachel houses her nefeš, the conclusion that this is actually taken for granted by the author can be inferred on the basis of the following considerations. ${ }^{29}$ It is clear from Gen. 35:14 that a masșēba invites libation and anointment: Jacob provides both for the mașēeb $\bar{a}$ which he erects in the place where he had his encounter with God. In fact, the mașêeba of Gen. 35:14 is likely to have been erected for Deborah, who, we have been told in v. 8, just died:

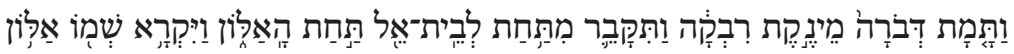

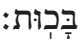

And Deb'orah, Rebekah's nurse, died, and she was buried under an oak below Bethel; so the name of it was called Al'lon-bacuth. (RSv)

29 On mașsēbōth, cf. J. Wellhausen, Reste arabischen Heidentums, second edition (Berlin, 1897), pp. 101-102; Smith, Lectures on the Religion of the Semites: The Fundamental Institutions, ed. S. A. Cook, third edition (New York and London, 1927), pp. 203-312; Z. Zevit, The Religions of Ancient Israel: A Synthesis of Parallactic Approaches (London and New York, 2001), pp. 256-665. The conceptualization of certain types of stones as dwellings of the souls of the departed seems to be a Northwest-Semitic speciality. Unlike Babylonian images of humans and deities, the stones are not considered to be "fractals of reality" (Z. Bahrani, The Graven Image: Representation in Babylonia and Assyria (Archaeology, Culture and Society; Philadelphia, 2003), p. 132) that are as "real" as the actual divine or human person to which they pertain and which, in modern terminology, they "signify". Rather, the stone is thought to house the soul, as we are demonstrating here with regard to Genesis 35 . 
As Joel Baden, deepening observations made by the classic proponents of the Documentary Hypothesis, has demonstrated, ${ }^{30}$ vv. 1-1.14.16b-18.20 are parts of the Elohistic source, whereas Vv. 9-93.15-56a.19 are Priestly. ${ }^{31}$ This is Baden's reconstruction of the Elohistic material in Gen. 35:1-10:

God said to Jacob, "Arise, go up to Bethel and remain there; and build an altar there to the God who appeared to you when you were fleeing from your brother Esau." 'So Jacob said to his household and to all who were with him, "Rid yourselves of the alien gods in your midst, purify yourselves, and change your clothes. ${ }^{3}$ Come, let us go up to Bethel, and I will build an altar there to the God who answered me when I was in distress and who has been with me wherever I have gone." ${ }^{4}$ They gave to Jacob all the alien gods that they had, and the rings that were in their ears; and Jacob buried them under the terebinth that was near Shechem. ${ }^{5}$ As they set out, a terror from God fell on the cities round about, so that they did not pursue the sons of Jacob. ${ }^{6}$ Thus Jacob came to Luz- that is, Bethel - in the land of Canaan, he and all the people who were with him. ${ }^{7}$ There he built an altar and named the site El-bethel, for it was there that God had revealed Himself to him when he was fleeing from his brother. ${ }^{8}$ Deborah, Rebekah's nurse, died, and was buried under the oak below Bethel; so it was named Allon-bacuth. ${ }^{14} \mathrm{Jacob}$ set up a pillar, a pillar of stone, and he offered a libation on it and poured oil on it. ${ }^{16}$ Rachel was in childbirth, and she had hard labor. ${ }^{17}$ When her labor was at its hardest, the midwife said to her, "Have no fear, for it is another boy for you." ${ }^{18}$ But as she breathed her last-for she was dying — she named his name Benoni; but his father called him Benjamin. ${ }^{20}$ Over her grave Jacob set up a pillar; it is the pillar at Rachel's grave to this day. ${ }^{32}$

The sequence of actions related to the mașșēboth is of central importance, and their original purpose suddenly becomes clear. Let us have a closer look at vv. 16-69: Rachel dies—in the words of v. 18: her nefeš proceeded-literally: went out - from her (the verb used is $y s_{\text {'). }}$. Once again Jacob puts up a mașseêba , this one he places "on her grave": a mașsêba which is referred to "to this day", the text says, as the "mașseēba of the grave of Rachel" (v. 20). Baden translates

$30 \quad$ J. S. Baden, The Composition of the Pentateuch: Renewing the Documentary Hypothesis (New Haven and London: Yale University Press, 2012).

31 Baden, Composition, pp. 233-337. Cf. J. Wellhausen, Die Composition des Hexateuchs und der historischen Bücher des Alten Testaments, second impression (Berlin, 1889), pp. 47-70. 
the beginning of v. 18 as "But as she breathed her last" and thus overlooks a key characteristic of the Elohistic narrative he has reconstructed, i.e., the fact that it stresses the departure of the nefeš from the body: "And when her nefeš was de-

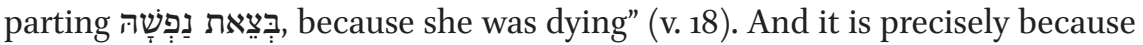
the nefes departs from the body that it can move into a mașểb - which is one of the central concerns of the Elohistic narrative in this section: the care for the living nefašoth of the deceased. We are not told about Jacob pouring libations on Rachel's mașşēba and anointing it, but we are implicitly encouraged to assume that he did, since he did precisely that, according to Gen. 35:14, on Deborah's mașsēba . Also, we are not explicitly told that Rachel's nefeš, after having proceeded from her body, entered the mașẹeb a that Jacob put up for her.

It is highly probable that what we have here is essentially the same practice as that of the sacrificial offering for Katumuwa. This can be concluded for the following reasons: on the basis of the parallel events and actions narrated in vv. 8 and 14, on the one hand, and vv. 14 and 20, on the other, it is safe to assume that they illuminate each other and that Rachel's mașseêba is thought to receive the same treatment as Deborah's, i.e., is used for libations. The libations in v. 14 and (implicitly) in v. 20 would be pointless without someone/something the libation is supposed to benefit. The object of the libation can, according to the context, only be the nefeš which has left the body. The mașếba of v. 14 is assumed to contain Deborah's nefeš, and that of v. 20 to house Rachel's nefeš: the Katumuwa inscription provides the key to understanding where the nefes is supposed to go, i.e., from the body into the mașșēba

It is not necessary to postulate a direct influence of Northern Syrian concepts of the $n b s ̌$ on the understanding of nefeš in the Southern Levant. Z. Zevit has shown how widespread the use of mașsēbōth was across the whole area in question, from the Negev to Phoenicia and northern Syria, and he has pointed out the close similarities between the standing stones, their uses, and the terminologies used to designate them across a number of Semitic cultures and languages. ${ }^{33}$ The Katumuwa inscription gives us the key to viewing the biblical evidence synoptically in the context of the evidence of standing stones across the various Semitic cultures in the area. It allows us to conclude that, in pre-exilic Israel and Judah, mașsēbōth were understood to house the deceased persons' nefašoth and thus give the deceased persons' relatives the opportunity to visit and feed them. This conclusion is supported by other texts and by archaeological finds which indicate that libations and ointments applied to such standing stones were sacrifices for the persons of the deceased. They were

33 Z. Zevit, The Religions of Ancient Israel: A Synthesis of Parallactic Approaches (London: Continuum, 2001), pp. 256-662. 
thought to live on in some way in the standing stone, or else such sacrifices would have made no sense.

Let us now turn to Psalm 16. There are those who think of it as an early, socalled "Canaanite" psalm, and others who date it to the third century. The key verses for the purposes of this investigation are vv. 10 and 11:

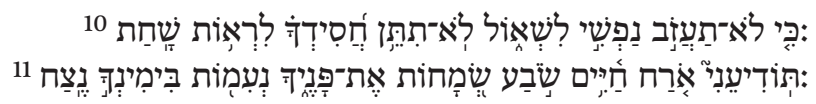

The RSv translates:

10

11
For thou dost not give me up to Sheol, or let thy godly one see the Pit.

Thou dost show me the path of life; in thy presence there is fulness of joy, in thy right hand are pleasures for evermore.

It thus circumvents the problem posed by the use of nefeš. Other translations are less evasive; cf. the KJv's rendering of v. 10: "For thou wilt not leave my soul in hell; neither wilt thou suffer thine Holy One to see corruption." The two translations exemplify the two main strands of interpretation: $\mathrm{V}$. 10 is typically interpreted either as a reference to the supplicant's soul, life, or person being saved from the netherworld after the point of physical death or as an indication of the preservation of the supplicant's life from dangers encountered in their earthly existence. ${ }^{34}$ It should be noted that neither "thy godly one" nor

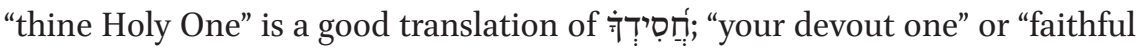
one" would be more appropriate.

Let us have a closer look at the verses. In v. 10, nafši is used, in v. 11 the 1st ps. pers. suff. is added to a form of $y d^{\prime}$ : the author thus clearly distinguishes between the use of nefes and the standard use of suffixes to refer to agents in the text. Therefore translating the crucial segment of v. 10 as "thou dost not give me up" is inadequate. That is confirmed by the fact that nafši and parallel: the nefeš is equated with the devout/faithful person. With regard to what will or will not happen to the nefeš, the psalmist states that God will not abandon it, will not leave it to Sheol. The verb ' $z b$ is used, in parallel with $y r$ ': just as much as the nefeš of the psalmist will not be abandoned, the faithful

34 On the remarkable variety of interpretations, see K. Liess, Der Weg des Lebens: Psalm 16 und das Lebens- und Todesverständnis der Individualpsalmen (FAT II/5; Tübingen, 2004), pp. 3-3o. 
one-i.e., the psalmist - will not see ששָח, that is, corruption, decomposition. The root $s-h-t$ refers to actual corruption (amongst Phoenician inscriptions, cf. KAI 24:15.16; amongst inscriptions in Aramaic, cf. šh̆t $t_{2}$ in KAI 215:2.7). To use it to refer to the burial pit means using it metonymically. The consequences of God's action are spelled out in v. 11: the faithful person will see the "path of life" and will experience the "fullness of joy" and eternal pleasures in the presence of the deity. The psalmist thus paints a picture of eschatological salvation for the individual who will forever be in the presence of the divine: v. 11 explicates v. 10 and illuminates the future state of the faithful person's nefes the nefeš, which is thought to encapsulate the whole person, is here viewed as being capable of eternal existence. The only adequate translation of nefeš, in

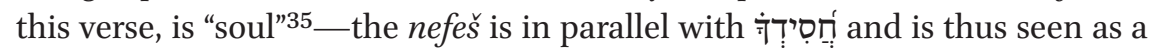
personal force, as an agent orientated towards the deity's salvation, which lies in the future, as is clarified by the context generally and the use of the verbs in particular.

Let us also cast an eye on Psalm 49:15-56: There is a contrast between the godless whose form (syr*4 "form" (in the sense of Gestalt), "image") "shall waste away in Sheol" (NJPS) and the nefeš of the psalmist which God will redeem from the "clutches of Sheol". The redeeming, or taking away from, is expressed through the same verb lq $h$ that we find applied to Enoch (Gen. 5:24) and Elijah (2 Kings 2 ) when they are taken up into heaven. ${ }^{36}$

\section{The Katumuwa Stele and the Conceptualization of nefeš in the} Hebrew Bible

Let us now summarize and interpret the evidence we have adduced. I should like to start with a longish quotation. I have chosen it because it is characteristic of a certain trend of interpreting the biblical and related evidence. Seth Sanders summarizes his views on nefeš and states that

35 Cf. H. Gese, "Der Tod im Alten Testament", in idem, Zur biblischen Theologie: Alttestamentliche Vorträge (BevTh 78; Munich, 1977), (pp. 31-14) p. 47: "Denn du (Gott) überläßt meine Seele [...] nicht dem Hades, / läßt nicht zu, daß dein Vertrauter die Grube sieht".

36 Thus Gese, "Tod", p. 45. With regard to the nefeš being in Sheol and about to be delivered from the netherworld, also cf. Psalms 16:10, 30:4, 49:16, 86:13, 89:49, Proverbs 23:14; and Isa. 38:17, Job 33:18, 22, 28, 3 o. 
neither in Sam'alian nor in the 756 instances of the cognate nefeš in the Hebrew Bible does it ever clearly appear in disembodied form, apart from a physical object (always human in the Bible, a stele at Zincirli). After death, the Biblical Hebrew nefeš has no separate existence; when it departs, it ceases to exist and, like the Ugaritic nps, "goes out (yș') like a light." In Priestly literature, it denotes the ritually significant aspect of a recently dead corpse. At Sam'al, the only attested postmortem role for the $n b s ̌$ is to eat, a role paralleled by its prominent biblical role as the seat of the appetites, crystallized in expressions such as 'awwat + nefes "craving," for meat in Dt 12:15, 20 and 1 Sam 2:16. ${ }^{37}$

Having examined the Katamuwa inscription and some of the biblical key texts, we can safely state now that Sanders's conclusion constitutes a misinterpretation of the evidence. Rather, texts like Genesis 35, Ezekiel 18, and Psalms 16, 42 and 49 demonstrate that blanket statements on the biblical use of nefeš, like the one just adduced, result from isolating biblical instances of the use of nefeš from their immediate literary contexts and their cultural and religious settings. In the case of Genesis 35, for example, Sanders overlooks the significance of $y s^{\prime}$ and becomes the victim of his own translation: $y s^{\prime}$ does mean "to go out", but not like a light-it means "to go out" in the sense of "to leave", "to proceed from", as in a number of Ugaritic texts, for example in the context of the murder of Aqhat, СTA/KTU $1.18 \mathrm{IV}$, when it is stated that his soul left the body, using the Ugaritic cognates of nefeš and yș. That is why an expression like nefeš mèt in Num. 6:6 and Lev. 21:11, referring to the soul of a dead person, is possible in the first place: because the underlying notion is that the nefes has left the (now dead) body. ${ }^{38}$

As we have seen, in pre-exilic Israel and Judah mașșēbōth were conceptu-

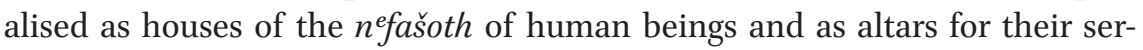
vice, including the cases of Jacob's anointing of and libation for the mașe $\bar{e} b \bar{a}$ of Deborah and of the mașsêba of Rachel in Genesis 35. KAI 214 and 215 and, strikingly, the Katumuwa stele are witnesses to the same practices, only in a more elaborate form. Both the mașsêeboth in Genesis 35 and the Katumuwa stele were thought to house the nefeš of departed persons. In this respect the Katumuwa stele - called a $n s ̦ b$ in its inscription, the Aramaic cognate of Hebrew mașsêbā-very much resembles the mașsêeōth known from the

37 Sanders, "The Appetites of the Dead", p. 44.

38 K. Elliger, Leviticus (Handbuch zum Alten Testament I/4; Tübingen, 1966), p. 288, also cf. ibid., n. 1 . 
Bible and through archaeological excavations, which also combine the two functions.

At least since the days of William Robertson Smith and Julius Wellhausen, there has been a debate, on and off, about the purpose of the mașșēbōth mentioned in the Hebrew Bible. Until very recent times, not that much progress had been made with regard to finding a definitive answer. In his work The Religions of Ancient Israel, with its extremely thorough discussion of cult places and objects, and especially of mașseēbōth, Ziony Zevit concludes with regard to mașseēbōth that they "were aniconic representations of the deity [i.e., Yhwh] whose function was to guarantee its presence when addressed". ${ }^{39}$ Others stress the connection with burial, but see mașsēbōth simply as "grave-markers".40 On the basis of our exploration of the biblical texts in conjunction with the Katamuwa inscription and stele, we can now conclude that mașẹēōth typically were neither of the two. They housed the nefašoth of the deceased in order for them to be fed and thus properly looked after in their post-mortem existence. The fact that mortuary steles can be called $n$ efašoth is explained by the belief that the soul enters its new "house" and the latter then becomes identified with the former. Georg Beer held that view, and published it, in 1921, but his conclusions were speculative and did not have much non-biblical evidence to support it. ${ }^{41}$ On the basis of the Katumuwa find, seen in conjunction with other Aramaic inscriptions and the biblical texts, especially the Elohistic material in Genesis 35, we can now confidently state that one of the main purposes of masșêbōth-maybe the main purpose-was to ensure the continued existence of the soul of the deceased person and its presence both amongst the living and simultaneously in the presence of the deity. ${ }^{42}$ This confirms that

39 Zevit, Religions of Ancient Israel, p. 261.

40 E. Bloch-Smith, Judahite Burial Practices and Beliefs About the Dead (JSOTSup 123; Sheffield, 1992), p. 113 and T. J. Lewis, "How Far Can Texts Take Us? Evaluating Textual Sources for Reconstructing Ancient Israelite Beliefs about the Dead", in B. M. Gittlen (ed.), Sacred Time, Sacred Place: Archaeology and the Religion of Israel (Winona Lake, Ind., 2002), pp. 169-917.

41 G. Beer, Steinverehrung bei den Israeliten: Ein Beitrag zur semitischen und allgemeinen Religionsgeschichte (Berlin and Leipzig, 1921).

42 Beer, Steinverehrung, p. 11: "Als der Mensch in sich die Seele entdeckte, hat er die Steinidole, ebenso wie er mit anderen heiligen Naturmalen verfuhr, mit einer Seele ausgestattet und in ihnen die Behausungen eines Einzelwesens gesehen. Da das Heilige, das in dem Stein verkörpert ist, das Wesen aller Dämonen, Geister und Götter bildet, kann schließlich der Stein Symbol und Abbild jeder Gottheit sein, so wie der Grabstein das Duplikat der einzelnen Totenseelen ist. Mit dem Kultstein deckt sich auf arabisch-israelitischem Gebiet die älteste Gestalt des Altars. Dann ist aber auch der altisraelitische Altar 
in ancient Israel the same notion existed as that found in Western Anatolian funerary monuments, of which Craig Melchert says "that the notion of the soul residing in the funeral stele is a result of the cultural synthesis that took place in the Syrian-Anatolian contact zone". 43

Different biblical authors had different concepts of the nature and significance of the human nefeš, but, as we have seen, to understand it as "soul" or "(essence of the) person" was clearly one of them. In fact, the views of some biblical authors and redactors, like those expressed by the Elohist in Genesis 35 , were virtually identical with those held by Katumuwa. Those of others were not: to name just one possibility, nefeš could be conceived of as simply indicating the vital force, desire, appetite, cf. Deut. 12:20-01, Jer. 2:24, Prov. 28:25. This divergence of views within the same literary collection is not surprising. Not only do we have a huge range of meanings of nefes in the Hebrew Bible, we also find that the conceptualizations of nefeš as soul or person are not uniform. Furthermore, they do not seem to follow any developmental pattern. But one thing is for sure: they existed, and they were expressed ritually. We can reconstruct the practice of feeding the souls or personal essences of individuals after those individuals' physical deaths. This conceptualization of an individual's nefeš and its post mortem existence and presence was an important part of the Israelites' view of the human condition, at least up to the seventh century,

ursprünglich ein Idol oder Fetisch: das Ebenbild der präsenten Gottheit. Erst in einem weiteren Entwickelungsstadium ist der israelitische Altar Gabetisch, Feuerherd und Räucherstätte geworden."

43 H. C. Melchert, "Remarks on the Kuttamuwa Inscription", Kubaba 1 (2010), (pp. 4-41) p. 9: "The reference in the Kuttamuwa inscription to a soul independent of the body is thus no novelty in Anatolia. As already indicated by David Schloen, the exciting genuinely new contribution of the text is the explicit statement that the soul of the deceased resides in the funeral stele, which offers confirmation of what has previously only been suspected. See the very cautious claim of Hutter (1993: 104) and also Watkins (2008: 136-6) on the common word for both 'funerary monument' and 'cult stele' in the western Anatolian Indo-European languages: HLuvian tasa(n)-za, Lycian $\vartheta \vartheta \tilde{e}$, Lydian tasẽv, etymologically *'possessing the sacred/divine'. As stressed by Hutter (1993: 103-3), it is striking that the Hittite word NA4huwaši- is used only to refer to cult steles believed to contain a deity and to boundary markers, never to funerary monuments (for a summary of uses see Puhvel 1991: 438-80). Since an Indo-European inheritance for the western Anatolian usage seems unlikely, one should rather consider that the notion of the soul residing in the funeral stele is a result of the cultural synthesis that took place in the Syrian-Anatolian contact zone (see already Hutter 1993: 105-5)." The reference to 'Hutter 1993' is to M. Hutter, "Kultstelen und Baityloi: Die Ausstrahlung eines syrischen religiösen Phänomens nach Kleinasien und Israel", in B. Janowski et al. (eds.), Religionsgeschichtliche Beziehungen zwischen Kleinasien, Nordsyrien, und dem Alten Testament (Göttingen, 1993), pp. 87-708. 
when the Deuteronomistic movement ${ }^{44}$ tried to suppress certain funerary rituals and the beliefs that provided their basis. This meant that concepts which implied some form of continued existence of the dead now came under the scrutiny of the propagators of the supposed purification of the Yahwistic religion, a purification that was in fact the consequence of new economic and social constellations in Judah ${ }^{45}$ as discussed by J. Blenkinsopp. ${ }^{46}$ The belief in the nefes as soul or personal essence provided that basis, and that is why the Pentateuch redaction tried to obfuscate its traces. Funerary cults are targeted by both the Deuteronom(ist)ic movement and the Priestly School (Num. 19:1116; Num. 31:19) as well as the Holiness School (cf. Lev 21:6), probably for the reasons given by Blenkinsopp in his application of Max Weber's insights. Both the Deuteronomic-Deuteronomistic view (cf. Deut. 26:14), possibly foreshadowed in Hos 9:1-1, ${ }^{47}$ and the Priestly views of the matter deeply influenced the work of redactors who worked on texts that betrayed older notions of nefeš as soul or person, as in the case of Genesis 35, where the traces of the archaic concept of the nefeš in the mașsêba was skilfully transformed into the notion of the mașsēbe as a memorial of God's presence.

The fact that we only have a few instances in the Hebrew Bible which clearly point to the concept of a soul must have to do with the marginalisation and attempted eradication of any ritualized action for the benefit of the dead. The conceptualization of nefeš as soul was suppressed because it was a constant reminder of the existence and attraction of traditional cults of pre-Israelite origin employing mașseēbōth and other objects that now seemed unacceptable.

The fact that many contemporary scholars cannot see that nefeš was conceptualized as soul—or, if preferred, essence of the person-during the

44 Cf. W. Groß (ed.), Jeremia und die deuteronomistische Bewegung (в в в 98; Weinheim, 1995), pp. $87-708$.

45 The same tendency can be detected in Trito-Isaiah; as Suriano, "Breaking Bread", p. 404, n. 95 rightly points out with regard to "the prophet" Trito-Isaiah: "Thus, the prophet was rejecting the foundations of the traditional kinship-based society."

46 J. Blenkinsopp, "Deuteronomy and the Politics of Post-Mortem Existence", VT 45 (1995), pp. 1-16, on the eradication of cults of the dead in Judah from the late pre-exilic period onwards is relevant here. Cf. Blenkinsopp on Dtn 12-26": "Since ancestor cult was an essential integrative element of a social system based on lineage, it was opposed in the name of a centralized state cult which claimed the exclusive allegiance of those living within the confines of the state. The laws concerning death rites and forbidding commerce with the dead in Deuteronomy were therefore part of a broader strategy of undermining the lineage system to which the individual household (bêt 'âa) belonged."

Cf. Suriano, "Breaking Bread". 
pre-exilic period is due to a number of intellectual constellations. The two most important ones are, in my view, (1) the weight of Deuteronomistic ideology in the biblical tradition and (2) a certain perception of what is intellectually responsible exegesis today. The former constellation dominates much of the biblical tradition and continues to dominate and prejudice the minds of many present-day exegetes when they go about their work, thus affecting their historical-philological work. The latter constellation leads to statements such as the following. Matthew Suriano writes in his very thorough study of the Katumuwa stele, when discussing its ritual use and location: "Within these

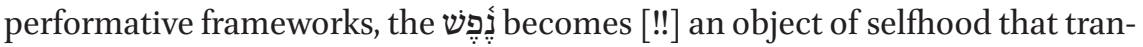
scends death." ${ }^{38}$ Also, he says: "The rituals that occur inside this space reify Katumuwa's self; that is, the act of feeding objectifies his defunct-soul within a specialized location." ${ }^{49}$ So Suriano concludes that while the Katumuwa inscription clearly speaks of the nefeš as a living entity present in the standing stone, and while nefeš should be translated as "soul", the soul was nevertheless conceptualized as becoming (instead of being!) "an object of selfhood" and that the feeding "objectifies" the soul in a certain location. We have here an interpretation of the evidence which is, in my view, dominated by the sense that, after the collapse of its metaphysical foundations in the late eighteenth and early nineteenth centuries, it no longer makes sense to speak of the soul as a distinct, permanent entity. Some exegetes seem to project that view onto ancient texts that are governed by the belief in a soul and relativize that belief: the soul "becomes" an "object of selfhood" where quite clearly the ancient text takes for granted that nefeš does not become, but is a permanent, distinct entity that is distinguishable from the body, inhabits the body, in some way encapsulates and expresses personhood, and leaves the body at the point of the person's physical death. The fact that this is so hard to grasp for contemporary Hebrew Bible scholarship is due to the lasting effect of a certain understanding of the Kantian criticism of traditional concepts of the soul that we have all imbibed. ${ }^{50}$ While, generally speaking, the insights, achievements and methods developed by the Enlightenment and the new approach to history which it triggered are the basis of everything we do, we must not let its philosophical notions stand in the way of exegetical attempts to uncover the meaning of ancient texts and

48 Suriano, "Breaking Bread", p. 393.

49 Suriano, "Breaking Bread", p. 396.

50 Barth, "Selbstbewußtsein und Seele", p. 201: "Kant ist der eigentliche Urheber des für die Moderne signifikanten Wandels vom Substanzdenken zum Funktionsdenken." That had a massive effect on all later conceptualizations of the soul and also adversely affected reconstructions of historical conceptualizations of the soul, as Barth demonstrates in his essay. 
artefacts. As we have seen, a self-reflexive comparativist approach to the study of North-West Semitic religious practices, combined with a fresh analysis of the relevant texts and artefacts, can advance the understanding of a key concept of ancient Israelite religion that permeates much of biblical literature. ${ }^{51}$

51 And if one extends the enquiry beyond the Hebrew Bible and into Jewish Hellenistic literature, including Jewish Hellenistic works that have traditionally been valued as scripture by the Christian Church, it becomes even more obvious what range of views of the nature of the soul existed: suffice it to mention the quasi-Stoic view of the soul, $\psi v \times \eta$, as an en-

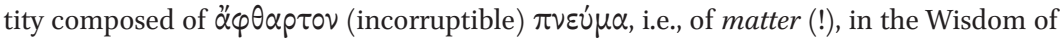
Solomon, as opposed to the Platonic view of the soul as non-material. In a sense, things come full circle in the Wisdom of Solomon: it is informed by a view of the soul as being material, as in Genesis 35 and the Katumuwa inscription, but for very different reasons and on the basis of a very different tradition. 